\title{
Diagnosis of contagious ecthyma in goats in a quarantine station in Panama
}

\author{
Diagnóstico de ectima contagioso en caprinos dentro de una \\ estación de cuarentena en Panamá
}

\author{
Angie Magaña Ch, ${ }^{1 *}$ MMVZ, Nathaniel Kadoch Z, ${ }^{2}$ M.Sc, Anarvik Sánchez $\mathrm{P}_{,}{ }^{3}$ M.Sc, \\ César Maure $\mathrm{M},{ }^{2} \mathrm{MV}$, Rolando Tello J, ${ }^{2}$ M.Sc.
}

\begin{abstract}
${ }^{1}$ Ministry of Agricultural Development, National Directorate of Animal Health, Laboratory of Diagnosis and Veterinary Research Dr. Gerardino Medina H., Río Tapia, Tocumen, Edificio LADIV, Panamá, Panamá. ${ }^{2}$ Ministry of Agricultural Development, Executive Management of Agricultural Quarantine, Altos de Curundu, Calle River, Building 577, Panamá, Panamá. ${ }^{3}$ Ministry of Agricultural Development, Laboratory of Vesicular Disease Diagnosis, Río Tapia, Tocumen, LADIVES Building, Panamá, Panamá. *Correspondence: patovetpanama@gmail.com
\end{abstract}

Received: September 2013; Accepted: April 2014.

\begin{abstract}
We report an outbreak of contagious ecthyma (CE) in a herd of goats at Paso Canoas quarantine station, Panama. The goats were adult intact females. Visible clinical signs became apparent from day 13 after the start of quarantine. We performed clinical examination. Serum biopsy and scabs were collected from crusted lesions in the epithelium of the lips, nose and eyelid corners. Samples were studied by histopathology,complement fixation test, transmission electron microscopy (TEM), DAS-ELISA, viral isolationand nucleic acid amplification tests. Histopathology revealed ortho and parakeratotic hyperkeratosis, epithelial hyperplasia, viral inclusion bodies, keratinocytes with balonoid degeneration, vesicles with neutrophils and degenerated cells, in superficial dermis there is marked neovascularization. Complement fixation test, DAS-ELISA and nucleic acid amplification tests resulted positive for contagious ecthyma. TEM showed viral particles, consistent with Parapoxvirus. Clinical and laboratory findings were consistent with poxvirus infection in the quarantine goat herd.
\end{abstract}

Key words: Disease prevention, goats, orf virus, parapoxvirus (Source: MeSH MEDLINE).

\section{RESUMEN}

El presente reporte describe un brote de ectima contagioso (EC) en un rebaño de cabras. Este caso tuvo lugar en la estación cuarentenaria de Paso Canoas, Panamá. Las cabras eran hembras, adultas, enteras y los signos clínicos fueron observados 13 días después de dar inicio al período de cuarentena. Se practicó el examen clínico, se colectaron fragmentos de costras y suero, además se realizaron biopsias de lesiones costrosas en el epitelio de los labios, nariz y comisuras palpebrales. Las muestras fueron analizadas por histopatología, prueba de fijación de complemento, microscopía electrónica de transmisión (MET), DAS-ELISA, aislamiento viral y amplificación de ácidos nucleicos. La histopatología reveló hiperqueratosis orto y paraqueratósica, hiperplasia epitelial, cuerpos de inclusión viral, eosinofílicos intracitoplasmáticos, degeneración balonoide de los queratinocitos, así como vesículas que contenían neutrófilos y células degeneradas; además, en la dermis superficial se observó una marcada 
neovascularización y edema. Las pruebas de fijación de complemento, DAS-ELISA y amplificación de ácidos nucléicos resultaron positivas para EC. El resultado de MET reveló partículas virales consistentes con Parapoxvirus. Los hallazgos clínicos y los resultados de laboratorio confirmaron el brote infeccioso de Parapoxvirus, agente etiológico de $\mathrm{EC}$, en el hato en cuarentena.

Palabras clave: Cabras, orfvirus, parapoxvirus, prevención de enfermedades (Fuente: MeSH MEDLINE).

\section{INTRODUCTION}

Contagious Ecthyma (CE) is an acute viral disease, with a benign, self-limiting course, affecting epithelia. It is not systemic, is important in public health, and is also related to high economic losses (1-3). This disease has not been reported in the Republic of Panama or in any of the groups of animals previously received at the Paso Canoas quarantine station.

The CE etiologic agent is a DNA virus, epitheliotropic $(2-4,6,7)$ of the Parapoxvirus genus, Poxviridae family (Orf virus) $(1,2,6,7)$. The Poxvirus is oval and the surrounding area is distinguished by a spiral tubule, characteristic of this family. The dimensions of the Poxvirus range from 220 to $300 \mathrm{~nm}$ in length $x 140$ to $170 \mathrm{~nm}$ in width (4).

CE affects ruminants, particularly sheep, and less frequently goats, and has been reported in humans $(1-8)$, dogs as well as in several wild species (1.4).

The infection in both animals and humans is transmitted by direct contact with the virus from infected animals, fomites, or grass; immunosuppressed animals and those with persistent infection keep the virus in the herd. The incubation period is four to eight days (1). The virus enters the body through broken skin and replicates in the cytoplasm of the host epithelial cell $(1-3,6,7)$. The first cellular changes observed are epithelial hyperplasia, balanoid degeneration of the stratum spinosum cells, hyperplasia of the basal membrane of the epidermis, edema and granulomatous inflammation and in a few days the lesions become pustules (1).

The lesions spontaneously disappear over a period that can last up to six weeks $(2,4,7-9)$, but there have been cases of CE that persist for a longer period in goats and sheep (7).

In goats, signs of CE are located in the epithelium of the lips, gingiva, tongue, nose, eyelid corners, inter-digital region, nipples, vulva and scrotum $(1,4,6,7)$. The most frequent clinical lesions include: erythematous macules $(1,2)$, papules $(1,2,7)$, vesicles $(1,2,4,10)$ and pustules $(1,2,4,7,10)$. These lesions progress to scabs $(1,2,7,8,10)$ and ulcers (7). $\mathrm{CE}$ is also known as sore mouth, contagious pustular dermatitis $(1,3,8,9)$, scabby mouth $(1,4,9)$, Orf (3$5,9)$ or cutaneous pustular dermatitis $(3,4)$.

\section{INTRODUCCIÓN}

Ectima contagioso (EC) es una enfermedad viral, aguda, de curso benigno y autolimitado, que afecta los epitelios, no es sistémica, tiene importancia en la salud pública y además, está relacionada con altas pérdidas económicas (13). Esta enfermedad no ha sido reportada en la Republica de Panamá ni en ninguno de los lotes de animales, recibidos anteriormente en la estación de cuarentena de Paso Canoas.

El agente etiológico de EC es un virus DNA, epiteliotrópico $(2-4,6,7)$, del género Parapoxvirus, familia Poxviridae (Orf virus) $(1,2,6,7)$. EL Poxvirus es ovalado y rodeando su superficie se distingue un túbulo en espiral característico de esta familia. Las dimensiones del Poxvirus varían desde 220 a $300 \mathrm{~nm}$ de longitud x 140 a $170 \mathrm{~nm}$ de ancho (4).

EC afecta rumiantes, principalmente ovinos y con menor frecuencia caprinos, se ha reportado en seres humanos (1-8), perros, así como en diversas especies silvestres $(1,4)$.

La infección tanto en animales como en el ser humano se trasmite por contacto directo con el virus, a partir de animales infectados, fómites, pasto; siendo los animales inmunosuprimidos y aquellos con infección persistente, los que mantienen el virus en el rebaño. El período de incubación es de cuatro a ocho días (1). El virus ingresa al organismo a través de la piel lacerada y se multiplica en el citoplasma de la célula epitelial hospedadora $(1-3,6,7)$. Los primeros cambios celulares que se observan son hiperplasia epitelial, degeneración balonoide de las células del estrato espinoso, hiperplasia de la membrana basal de la epidermis, edema e inflamación granulomatosa y en unos cuantos días las lesiones se convierten en pústulas (1).

Las lesiones desaparecen espontáneamente en un período que puede durar hasta seis semanas $(2,4,7-9)$, pero se han reportado casos de EC que persisten por un período mayor en cabras y ovejas (7).

En las cabras, los signos de EC se localizan en el epitelio de los labios, gingiva, lengua, nariz, comisuras palpebrales, región interdigital, 
CE morbidity may reach $100 \%$ of the animals during an outbreak. However, mortality is low, and is usually linked to the presence of bacterial infections $(1,2,4,7-10)$ and secondary fungal infections (7).

Clinical observation of lesions may suggest the presence of CE in the herd. However, the characteristic CE lesions can be similar to those observed in foot and mouth disease, goat pox, vesicular stomatitis, Staphylococcal dermatitis, dermatophilosis, ulcerative dermatosis $(1,7)$ and blue tongue (7). Definitive diagnosis of CE requires laboratory tests that allow confirmation of the virus $(2,7)$. This report describes an outbreak of Contagious Ecthyma (CE) in a herd of goats that took place at the Paso Canoas quarantine station in Panama.

\section{CLINICAL CASE}

In October 2012, an import of 214 intact female goats was received at the Paso Canoas Ministry of Agricultural Development quarantine station, located 200 meters from the border between Panama and Costa Rica. This herd of goats was moved by land and entered Panama through the Paso Canoas border and would fulfill a quarantine period of fifteen days at the quarantine station before being delivered to the owner. Upon arrival, all animals were inspected and a serum sample was collected from each one. Four (1.9\%) animals died during the first 24 hours after arrival in Panama. The technical staff at the quarantine station determined that these deaths were associated with bloat. Four (1.9\%) animals were serologically positive for Caprine Arthritis Encephalitis (CAE). Additionally, the animals showed some of these conditions or a combination thereof: poor body condition, pregnancy, mucopurulent nasal discharge, frequent coughing and overgrown hooves.

Clinical History. After 13 days of quarantine, $11(5.2 \%)$ animals had erythematous lesions and were devoid of hair on the lips, nose and palpebral fissures. At day 18, a total of 105 (50\%) animals were affected with lesions similar to those described above. The characteristics of the lesions and the morbidity were suggestive of a viral process. The team considered ruling out the following differential diagnoses: CE, goat pox, foot and mouth disease, vesicular stomatitis, staph dermatitis, dermatophilosis, bluetongue and ulcerative dermatosis.

Quarantine facilities were disinfected daily with Virkon S (Antec International Ldt., England) diluted to $100 \mathrm{ppm}$ and insect control was performed with Nuvan EC 1000 (Chemical Formulations $\mathrm{SA}$, Costa Rica) at a dilution of $1.5 \mathrm{ml} / \mathrm{L}$ water. pezones, vulva y escroto $(1,4,6,7)$. Las lesiones clínicas más frecuentes incluyen: máculas eritematosas $(1,2)$, pápulas $(1,2,7)$, vesículas $(1,2,4,10)$ y pústulas $(1,2,4,7,10)$. Estas lesiones evolucionan a costras $(1,2,7,8,10)$ y úlceras (7). EC también es conocida como boca dolorosa, dermatitis pustular contagiosa $(1,3,8,9)$, boca costrosa $(1,4,9)$, Orf $(3-5,9)$ o dermatitis pustular cutánea $(3,4)$.

La morbilidad de EC puede alcanzar al $100 \%$ de los animales durante un brote. Sin embargo, la mortalidad resulta baja, usualmente ligada a la presencia de infecciones bacterianas $(1,2,4$, 7-10) y fúngicas secundarias (7).

La observación clínica de las lesiones puede sugerir la presencia de EC en el rebaño. Sin embargo, las lesiones características de EC pueden ser similares a las observadas en fiebre aftosa, viruela caprina, estomatitis vesicular, dermatitis por Estafilococos, dermatofilosis, dermatosis ulcerativa $(1,7)$ y lengua azul (7). El diagnóstico definitivo de EC requiere de pruebas de laboratorio que permitan la confirmación del virus $(2,7)$. El presente reporte describe un brote de ectima contagioso (EC) en un rebaño de cabras que tuvo lugar en la estación cuarentenaria de Paso Canoas, Panamá.

\section{CASO CLÍNICO}

En octubre del 2012, se recibió una importación de 214 cabras hembras, enteras, en la estación cuarentenaria de Paso Canoas del Ministerio de Desarrollo Agropecuario, localizada a 200 metros lineales de la frontera de Panamá con Costa Rica. Este rebaño de cabras fue trasladado por vía terrestre e ingresó a Panamá a través del puesto fronterizo de Paso Canoas y cumpliría un periodo de cuarentena de quince días en la estación cuarentenaria, antes de ser entregados al propietario. A su llegada, todos los animales fueron inspeccionados y de cada uno se colectó una muestra de suero. Cuatro $(1.9 \%)$ animales murieron durante las primeras 24 horas después de su llegada a Panamá. El personal técnico de la estación cuarentenaria determinó que dichas muertes estaban asociadas a timpanismo. Cuatro (1.9\%) animales fueron serológicamente positivas a artritis encefalitis caprina (AEC). Adicionalmente, los animales presentaban algunas de estas condiciones o la combinación de las mismas: mala condición corporal, preñez, secreción nasal mucopurulenta, tos frecuente y pezuñas sobrecrecidas.

Historia clínica. Transcurridos 13 días de iniciada la cuarentena, $11(5.2 \%)$ animales presentaron 
The initial diet was based on concentrate and was replaced with fresh grass to avoid aggravating lesions on the lips.

\section{RESULTS}

Clinical examination findings. In general, the physiological variables were within the normal range for the species. The animals were maintained a good appetite but with poor body condition, mucopurulent nasal discharge, coughing and overgrown hooves. On the lips, nose and palpebral fissures, shiny and hairless erythematous macules were observed, as well as vesicles and pustules, these lesions bleed easily when touched. At 11 days after the onset of clinical signs, the lesions evolved into scabs, multifocal and coalescing ulcers as a result of the detachment of the crusts (Figure 1 ).

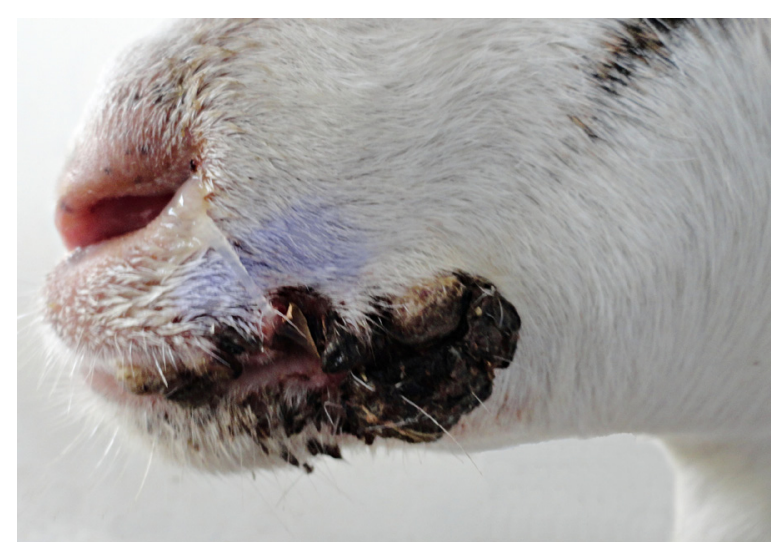

Figure 1. Left side view of the head. Lips show dark brown scabs. Translucent mucus coming out of the nostril is observed.

Samples of skin lesions (10 animals), serum (5 animals) and cobalt (20 animals) were collected. The samples obtained were analyzed by histopathology, virus isolation, DAS-ELISA and nucleic acid amplification, following the standard procedures $(11,12)$. Also, scab and serum samples were sent to the National Laboratory of Veterinary Services APHIS-USA (Ames, Iowa, USA) in order to perform the complement fixation test and transmission electron microscopy (TEM).

\section{Conventional histopathological analysis} of skin samples. The stratum corneum of the epidermis shows hyperkeratosis (ortho-and parakeratotic). In some sections of the lucid and granular stratum, the keratinocytes are degenerated (balanoid degeneration) with pyknotic nuclei and eosinophilic and refractile intracytoplasmic inclusions. Degenerated keratinocytes arise, leading to the formation of vesicles occupied by neutrophils and pus cells. The latter extend to the superficial lesiones eritematosas y desprovistas de pelo en los labios, nariz y comisuras palpebrales. Al día 18 , un total de 105 (50\%) animales estaban afectados con lesiones similares a las antes descritas. Las características de las lesiones y la morbilidad eran sugestivas de un proceso viral. El equipo de trabajo consideró descartar los siguientes diagnósticos diferenciales: EC, viruela caprina, fiebre aftosa, estomatitis vesicular, dermatitis por estafilococos, dermatofilosis, lengua azul y dermatosis ulcerativa.

Las instalaciones de cuarentena se desinfectaron diariamente con Virkon S (Antec Internacional Ldt., Inglaterra) diluido a $100 \mathrm{ppm}$ y el control de insectos se realizó con Nuvan EC 1000 (Formulaciones Químicas SA, Costa Rica) a una dilución de $1.5 \mathrm{ml} / \mathrm{L}$ de agua.

La dieta inicial estuvo basada en concentrado y se reemplazó por pasto fresco para evitar agravar las lesiones de los labios.

\section{RESULTADOS}

Hallazgos al examen clínico. En general, las variables fisiológicas estaban dentro de los rangos normales para la especie. Los animales se mantenían con buen apetito aunque con mala condición corporal, secreción nasal mucopurulenta, tos y pezuñas sobrecrecidas. En los labios, nariz y comisuras palpebrales, se observaron máculas eritematosas, brillantes y desprovistas de pelo, así como vesículas y pústulas, estas lesiones sangraban fácilmente al tacto. A 11 días de iniciados los signos clínicos, las lesiones descritas evolucionaron a costras, multifocales coalescentes y úlceras como resultado del desprendimiento de las costras (Figura 1).

Se colectó muestras de piel lesionada (10 animales), suero (5 animales) y costras (20 animales). Las muestras obtenidas fueron analizadas por histopatología, aislamiento viral, DAS-ELISA y amplificación de ácidos nucleicos, siguiendo los procedimientos de rutina (11, 12). Asimismo, se enviaron muestras de costras y suero, al Laboratorio Nacional de Servicios Veterinarios de APHIS-USA (Ames, Iowa, USA) para la realización de prueba de fijación de complemento y microscopía electrónica de transmisión (MET).

Análisis histopatológico convencional de las muestras de piel. El estrato córneo de la epidermis muestra hiperqueratosis (orto y paraqueratósica). En algunas secciones del estrato lúcido y granuloso, los queratinocitos están degenerados (degeneración balonoide) 
dermis. The dermis showed neovascularization with congestion, edema and hemorrhage (Figure 2).

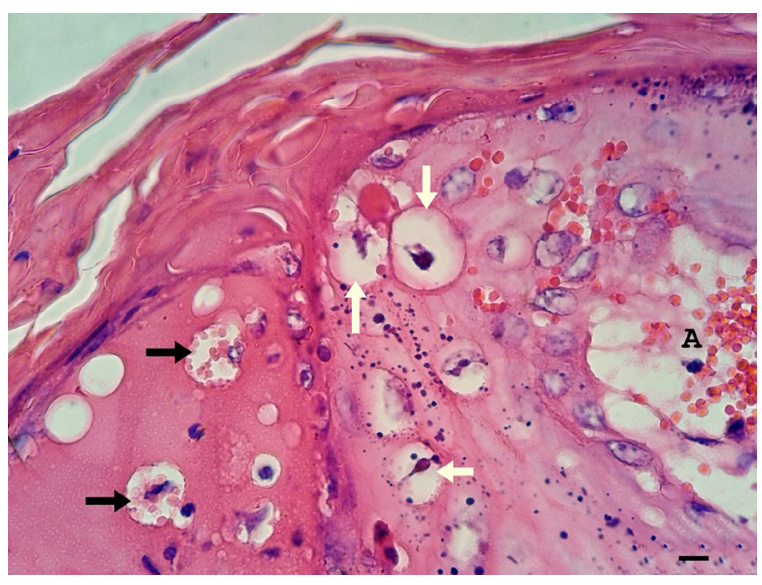

Figure 2. A. Skin sample with neovascularization, hematoxylin and eosin staining, 100X, bar $=100 \mu \mathrm{m}$. Epidermis and superficial dermis. The black arrow shows neovascularization. Congestion and edema located in the A. zone. B. Skin sample with scabs, hematoxylin and eosin staining, 400X, bar $=100 \mu \mathrm{m}$. Epidermis and superficial dermis. Hyperkeratosis in the A zone. The black arrows show intracytoplasmic inclusions. The white arrows indicate the balanoid degeneration of keratinocytes.

Viral isolation and DAS-ELISA. The DAS-ELISA test was performed on scabs for the detection of vesicular stomatitis and foot and mouth disease. The scabs were also used to inoculate Vero cells and in a period of less than 24 hours, the cytopathic effect was apparent. The DAS-ELISA technique was applied again, but this time the average with viable viral particles were isolated. Both scabs and viral particles were negative for vesicular stomatitis and foot and mouth disease.

Nucleic acid amplification test. DNA was extracted from the scabs, and from the viral particles isolated in Vero cells. Individual amplification of nucleic acids was performed for vesicular stomatitis, foot and mouth disease and contagious ecthyma. Viral amplification was only observed in all samples processed for the diagnosis of contagious ecthyma (Figure 3 ).

Serology. The complement fixation test was positive for CE for four of the five animals tested.

Transmission electron microscopy (TEM). TEM results showed electron-dense, ovoid, viral structures, with a crosslinked membrane pattern. The size of these structures was $308 \mathrm{~nm} \times 207 \mathrm{~nm}$ and they were consistent with the Parapoxvirus genus (Figure 4). con núcleos pignóticos e inclusiones intracitoplasmáticas, eosinofílicas y refringentes. A su vez queratinocitos degenerados se desprenden dando paso a la formación de vesículas ocupadas por neutrófilos y piocitos. Estos últimos se extendian hasta la dermis superficial. La dermis presentaba neovascularización con congestión, edema y hemorragia (Figura 2).

Aislamiento viral y DAS-ELISA. Se realizó la prueba de DAS-ELISA a las costras para la detección de estomatitis vesicular y fiebre aftosa. Las costras también fueron usadas para inocular células Vero y en un período inferior a 24 horas se observó el efecto citopático. Nuevamente se aplicó la técnica DAS-ELISA, pero en esta ocasión al medio con partículas virales viables, aisladas. Tanto las costras como las partículas virales fueron negativas para estomatitis vesicular y fiebre aftosa.

Prueba de amplificación de ácidos nucléicos. EI ADN fue extraído de las costras, así como de las partículas virales aisladas en las células Vero. Se realizó la amplificación de ácidos nucléicos individual para estomatitis vesicular, fiebre aftosa y ectima contagioso. Solamente, se observó amplificación viral en todas las muestras procesadas para diagnóstico de ectima contagioso (Figura 3).

Serología. La prueba de fijación de complemento resultó positiva a EC para cuatro de los cinco animales analizados.

Microscopía electrónica de transmisión (MET). Los resultados de la MET mostraron estructuras virales ovoides, electrodensas con un patrón de membrana entrecruzado. El tamaño de estas estructuras fue de $308 \mathrm{~nm} \times 207 \mathrm{~nm}$ y fueron consistentes con el género parapoxvirus (Figura 4).

\section{DISCUSIÓN}

En esta comunicación se reporta el diagnóstico de un brote de EC en la estación cuarentenaria de Paso Canoas, Panamá. Este brote ocurrió en un rebaño de cabras importadas a los 13 días de iniciada su cuarentena, los animales no fueron liberados en el territorio panameño.

Esta enfermedad no ha sido reportada en la República de Panamá, ni en ninguno de los lotes de animales importados recibidos en la estación cuarentenaria. Asimismo, en el país fronterizo más cercano, Costa Rica, tampoco hay reportes escritos de EC. 


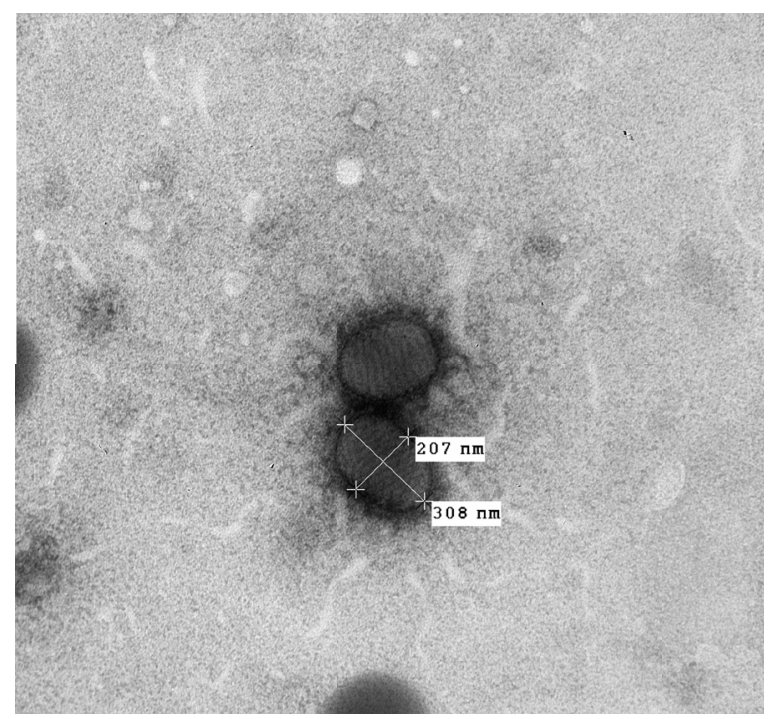

Figure 3. Nucleic acid amplification by PCR, wherein the product is shown amplified $350 \mathrm{pb}$. Lane 1: negative control, Lanes 2 and 3: positive control for CE. Lanes 4 to 9: Scab samples. Lanes 10 to 15: virus isolated in Vero cells.

\section{DISCUSSION}

This message reports the diagnosis of a CE outbreak in the Paso Canoas quarantine station in Panama. This outbreak occurred in a herd of imported goats at 13 days into their quarantine, the animals were not released in Panamanian territory.

This disease has not been reported in the Republic of Panama, or in any of the groups of imported animals received by the quarantine station. Also, in the nearest border country, Costa Rica, there are no written reports of CE.

In this outbreak, erythematous macules were apparent after 13 days of quarantine, which differs from literature that mentions a 4-8 day incubation period (1); Also, according to consulted literature, CE mainly affects young animals and sheep (1-3, $7,8)$, at this point it is important to mention that the quality and intensity of the infection could be related to the immune system's ability to control virus multiplication (1-3); the trip and other stressors may have played an important role in the timing of the disease. Also, one cannot dismiss the presence of persistently infected animals, which keep the virus circulating in the herd.

These lesions were exclusively distributed on the lips, nose and palpebral fissures. The distribution pattern of the lesions differs with that reported in literature where lesions can occur on the rest of the skin, genitals, udders and even on digestive epithelia $(1,2,4,8,10)$.

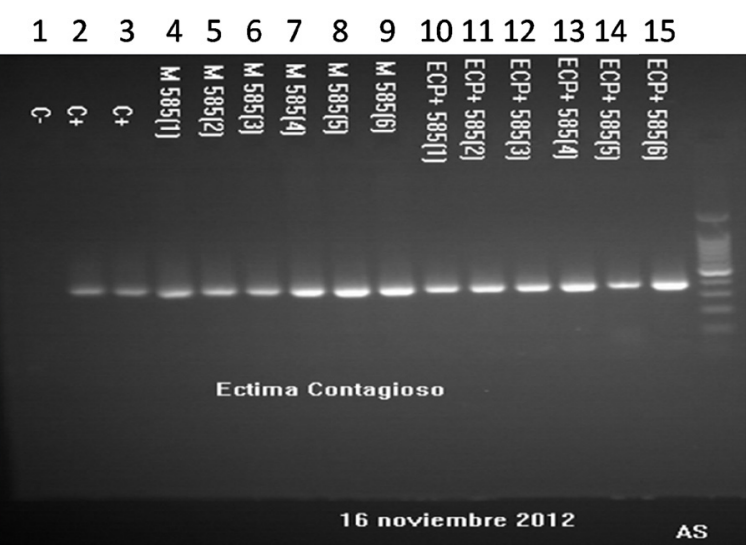

Figure 4. Transmission electron microscopy (TEM), negative staining. The image shows two viral particles with morphology and dimensions that are compatible with Parapoxvirus.

En este brote se observaron máculas eritematosas transcurridos 13 días de iniciada la cuarentena, lo cual difiere con la literatura que menciona 4 a 8 días como período de incubación (1); asimismo, según la literatura consultada, EC afecta principalmente a animales jóvenes y a ovejas $(1-3,7,8)$, en este punto es importante mencionar que la calidad e intensidad de la infección estaría relacionada con la capacidad del sistema inmunitario de controlar la multiplicación del virus (1-3); por que el viaje y otros factores estresantes, pudieron haber jugado un papel importante en el tiempo de presentación de la enfermedad. Tampoco se puede descartar la presencia de animales con infección persistente, los cuales mantienen el virus circulando en el rebaño.

Estas lesiones estuvieron distribuidas exclusivamente en los labios, nariz y comisuras palpebrales. El patrón de distribución de las lesiones observadas, difiere con el reportado en la literatura donde las lesiones pueden presentarse en el resto de la piel, órganos genitales, ubres e incluso en epitelios digestivos $(1,2,4,8,10)$.

Usualmente, las lesiones agudas y eritematosas evolucionan a costras en aproximadamente seis semanas (1). Sin embargo, en este caso, los caprinos mostraron formación de costras desde el día 11 después de iniciadas las lesiones macroscópicas agudas.

En la histopatología, las muestras de piel mostraron hiperqueratosis, degeneración balonoide de los queratinocitos, cuerpos de inclusión eosinofilicos, intracitoplasmáticos, infiltrado neutrofilico, neovascularización 
Usually, acute erythematous lesions progress to scabs in about six weeks (1). However, in this case, the goats showed scabbing on day 11 after the start of acute macroscopic lesions.

In the histopathology, skin samples showed hyperkeratosis, balanoid degeneration of keratinocytes, neutrophilic infiltrated, intracytoplasmic, eosinophilic inclusion bodies, neovascularization with congestion, edema and hemorrhage. These lesions are characteristic of CE $(1,7,10)$.

Clinical, histopathological and TEM diagnosis of CE were confirmed. The presence of other vesicular viral diseases was ruled out by means of the complement fixation test, DAS-ELISA and nucleic acid amplification tests.

Viral diseases such as foot and mouth disease, vesicular stomatitis, blue tongue and goat pox are differential diagnoses of $\mathrm{CE}$, and are also considered important diseases for quarantine. For this reason, and upon reaching the etiologic agent of the disease described in this report, it was necessary to discard the presence of other diseases.

Biosecurity and disinfection measures were based on the physicochemical properties of the virus of the Poxvirus genus. These viruses are sensitive to high temperatures, and to benzene (5) which contains Virkon S.

CE in ruminants affects the development of the livestock industry (8), since CE outbreaks cause economic losses related to decreased food intake and lower weight gain $(1,2,6,7)$. Furthermore, CE has an impact on animal welfare due to pain caused by lesions on the animal (2) and is of importance in public health as zoonosis (1-8).

Effective therapy against Parapoxvirus infection remains contentious. $(1,2,7)$. The goats also didn't have a severe bacterial infection. Therefore, animals affected with CE remained without drug treatment. Only feed was improved with fresh grass as a palliative treatment. After confirmation of CE in the herd, all animals were returned by land to their country of origin.

Quarantine stations are points of disease contention of vital importance to the country. Disease outbreaks in these facilities should be contained through strict biosecurity measures and diagnostic tests that establish the specific etiologic agent in the shortest possible period of time. For all imported animals, clinical inspection and alertness must be maintained in the event of any signs of disease manifestation during quarantine. con congestión, edema y hemorragia. Dichas lesiones son características de $\operatorname{EC}(1,7,10)$.

Se confirmó el diagnóstico clínico, histopatológico y de MET de EC. La presencia de otras enfermedades virales vesiculares fue descartada por medio de prueba de fijación de complemento, DAS-ELISA y pruebas de amplificación ácidos nucléicos.

Enfermedades virales como fiebre aftosa, estomatitis vesicular, lengua azul y viruela caprina son diagnósticos diferenciales de EC, también consideradas enfermedades de importancia para la cuarentena, por tal motivo además, de llegar al agente etiológico de la enfermedad descrita en este reporte, fue necesario descartar la presencia del resto de las enfermedades.

Las medidas de bioseguridad y desinfección estuvieron basadas en las propiedades fisicoquímicas de los virus del género Poxvirus. Estos virus son sensibles a altas temperaturas, así como al benceno (5) que contiene Virkon S.

La EC en los rumiantes afecta el desarrollo de la industria ganadera (8), ya que los brotes de EC ocasionan pérdidas económicas relacionadas con disminución en el consumo de alimentos y baja ganancia de peso $(1,2,6,7)$. Por otro lado, la EC tiene un impacto en el bienestar animal debido al dolor que producen las lesiones sobre el animal (2) y es de importancia en la salud pública por ser considerada zoonosis (1-8).

La terapia eficaz contra la infección de Parapoxvirus continúa en discusión. $(1,2,7)$. Las cabras tampoco presentaron infección bacteriana severa. Por tal motivo, los animales afectados con EC permanecieron sin tratamiento medicamentoso. Únicamente se mejoró la alimentación con pasto fresco como tratamiento paliativo. Después de la confirmación de EC en el rebaño, todos los animales retornaron por vía terrestre hasta el país de origen.

Las estaciones para cuarentena son puntos de contención de enfermedades de vital importancia para el país. Los brotes de enfermedades dentro de dichas instalaciones deben contenerse por medio de medidas estrictas de bioseguridad y pruebas diagnósticas que establezcan el agente etiológico específico en el menor tiempo posible. En todos los animales que se importen, se debe mantener la alerta y la inspección clínica ante cualquier manifestación de enfermedad durante la cuarentena. 


\section{Acknowledgements}

The authors acknowledge the financial, technical and logistical support of the following people and institutions: Dr. Enrique Evans, Dra. Kirian Cerceño, Dr. José Barrera, Licda. Yiris Rovira, Dr. Enzo Rodríguez, Dr. Manuel González Cano, Dr. Bredio Velasco, Dr. Humberto Hernández, Dr. Francisco Pinilla, Dr. Franklin Clavel, Dr. Carlos Lorenzo, Licda. Cristella Martínez y Licda. Krislly Ramírez from the Ministry of Agricultural Development and Palo Alto Laboratory of the México-United States Commission for the prevention of foot and mouth disease and other exotic diseases (CPA).

\section{Agradecimientos}

Los autores agradecen la colaboración financiera, técnica y logística de las siguientes personas e instituciones: Dr. Enrique Evans, Dra. Kirian Cerceño, Dr. José Barrera, Licda. Yiris Rovira, Dr. Enzo Rodríguez, Dr. Manuel González Cano, Dr. Bredio Velasco, Dr. Humberto Hernández, Dr. Francisco Pinilla, Dr. Franklin Clavel, Dr. Carlos Lorenzo, Licda. Cristella Martínez y Licda. Krislly Ramírez del Ministerio de Desarrollo Agropecuario y al Laboratorio de Palo Alto de la Comisión MéxicoEstados Unidos para la prevención de la Fiebre Aftosa y otras enfermedades exóticas (CPA).

\section{REFERENCES}

1. Nandi S, De U, Chowdhury S. Current status of contagious ecthyma or orf disease in goats and sheeps-a global perspective. Small Rumin Res 2011; 96:73-82.

2. Cea M, Reyes E, Bravo A, Rojas R. Estandarización de una técnica molecular para el diagnóstico de virus orf útil en la ganadería ovina. Ciencia y trabajo 2008; 28:39-46.

3. Wet C, Murie W. Lamb pays lip services: two cases of ecthyma contagiosum (Orf). Scott Med J 2011; 56(1):1-4.

4. De La Concha-Bermejillo A, Guo J, Zhang Z, Waldron $D$. Severe persistent orf in Young goats. J Vet Diagn Invest 2003; 15(5):423-431.

5. Gallina L, Scagliarini A. Virucidal efficacy of common disinfectants against orf virus. Vet Rec 2010; 166(23):725-726.

6. Musser J, Taylor C, Guo J, Tizard I, Walker J. Development of a contagious ecthyma vaccine for goats. Am J Vet Res 2008; 69(10):13671370.
7. Hosamani M, Scagliarini A, Bhanuprakash V, McInnes C, Singh R. Orf: an update on current research and future perspectives. Expert Rev Anti Infect Ther 2009; 7(7):879-893.

8. Hosie B. Orf: reasons to take an interest in control. Vet Rec 2012; 170:671-672.

9. Lovatt F, Barker W, Brown D, Spooner R. Casecontrol study of orf in preweaned lambs and an assessment of the financial impact of the disease. Vet Rec 2012; 170(26):673.

10. Sargison N, ScottP, Rhind S. Unusual outbreak of orf affecting the body of sheep associated with plunge dipping. Vet Rec 2007; 160:472-373.

11. Devi B, A.R. S, Parameaswari P, Parijathan B. Domestic microwave versus conventional tissue processing: a quantitative and qualitative analysis. J Clin Diagn Res 2013;7(5):835-839.

12. Kottaridi $C$, Nomikuo $K$, Lelli $R$, Markoulatos $P$, Mangana O. Laboratory diagnosis of contagious ecthyma: comparison of different PCR protocols with virus isolation in cell culture. J. Virol. Methods 2006; 134(1-2):119-124. 